\title{
Frequency of occurrence of affections of the adnexa and external eye
}

\author{
Frequência de ocorrência das afecções \\ dos anexos oculares e do olho externo
}

Maria Julia de Barros Orsolini ${ }^{1}$, Roberta Lilian de Sousa Fernandes Meneghim', Carlos Roberto Padovani², lury Lima Veloso ${ }^{1}$, Silvana Artioli Schellini ${ }^{1}$

\begin{abstract}
Purpose: To observe the frequency of occurrence of affections involving the adnexa or the external eye, as well as to describe the demographic profile of patients. Methods: A prospective, population based, randomized study was done in the Midwest region of the state of São Paulo, in the years 2004/2005. Using a Mobile Ophthalmic Unit we evaluated 11,000 people. A comprehensive eye exam was performed. Data were transferred to excel table and for this study we used information relating to annexes and external eye diseases. The frequency of occurrence of the problems detected was statistically analyzed. Results: We identified 1,581(14.4\%) disorders in the adnexa or in the external eye. The most common disorders were pterygium $(9.4 \%)$, hordeolum $(0.8 \%)$ and changes in eyelid position (1.7\%) (ectropion, ptosis and trichiasis). Trauma, ectropion and pterygium were statistically more frequent in the male population. Conclusion: Of the surveyed disorders the most frequent in the population was pterygium, followed by inflammatory changes and alterations in the eyelid position.
\end{abstract}

Keywords: Eye/pathology; Measures of disease occurrence

\section{ReSUMO}

Objetivo: Observar a frequência de ocorrência das afecções que acometem os anexos oculares e o olho externo, assim como descrever o perfil demográfico dos portadores, na região centro oeste do estado de São Paulo. Métodos: Estudo prospectivo, populacional e aleatorizado, no qual foram avaliadas 11.000 pessoas da região centro-oeste do Estado de São Paulo, nos anos de 2004/2005, por meio de consultas oftalmológicas e utilizando uma unidade móvel. Foi realizado exame oftalmológico completo. Os dados foram transferidos para tabela Excel, utilizando-se para o presente estudo dados referentes aos anexos e doenças do olho externo. A frequência de ocorrência dos problemas detectados foi analisada estatisticamente. Resultados: Foram detectadas 1.581 $(14,6 \%)$ afecções de anexos ou do olho externo, sendo as mais frequentes o pterígio $(9,4 \%)$, o hordéolo $(0,8 \%)$ e as alterações do posicionamento palpebral (1,7\%) (ectrópio, ptose e triquíase). Trauma, ectrópio e pterígio foram estatisticamente mais frequentes na população masculina. Conclusão: Das afecções pesquisadas, a de maior ocorrência na população foi o pterígio, seguido das alterações inflamatórias e do posicionamento palpebral.

Descritores: Olho/patologia; Medidas de ocorrência de doença

\footnotetext{
'Departamento de Oftalmologia, Otorrinolaringologia e Cirurgia de Cabeça e Pescoço, Faculdade de Medicina de Botucatu, Universidade Estadual Paulista "Júlio de Mesquita Filho", Botucatu, SP, Brasil.

2 Departamento de Bioestatística, Instituto de Biociências, Universidade Estadual Paulista "Júlio de Mesquita Filho, Botucatu, SP, Brasi

Faculdade de Medicina de Botucatu - UNESP

The authors declare no conflicts of interests.

Received for publication 10/12/2015 - Accepted for publication 08/04/2016
}

Rev Bras Oftalmol. 2016; 75 (3): 205-8 


\section{INTRODUCTION}

$\mathbf{T}$ The knowledge of the anatomy and disorders involving the eye adnexas and external eye is of extreme importance in the formation of the General physician and ophthalmologist.

The eye annexes are key structures for adequate ocular protection, particularly the external eye. They consist of eyelids, orbit (walls and content), and lacrimal channels, and have intimate contact with the ocular surface comprising the conjunctiva and cornea ${ }^{1}$.

Changes in the annexes may cause irreversible damage to the eye bulb, and the vast majority can be treated early or be avoidable ${ }^{2}$.

The discovery, approach and forms of treatment should be widely taught since the graduation course in Medicine to ophthalmology residents and health officials, so that late and irreversible complications to the eye are avoided.

In order to analyze the most common diseases that are found in the population, and with the aim of designing strategies for approach and educational target of training the general physician and ophthalmologist, we conducted this study with the objective to observe the frequency of occurrence of conditions that affect the eye adnexas and external eye, as well as describe the demographic profile of the patients.

\section{MethodS}

The present study was based on data collected in a specific general population, which was attended by individuals who have been randomly chosen, not necessarily patients of ocular diseases, in a cross-sectional, observational study, held between March 2004 and June 2005 in eleven cities in the midwest of the State of São Paulo, for which the reference center is the city of Botucatu. The participants were randomly determined, taking into account the address and based on the census of IBGE (Census, 2000). The sample size of 11000 individuals was established based on the total number of inhabitants in the region of study and the prevalence of blindness and low vision in the population examined. We examined 4305 (39.1\%) male patients and $6695(60.9 \%)$ female. The approach was made at a Mobile Ophthalmic Unit, being assessed demographic data and complete eye exam. All data was registered in Excel table. The present study considered diseases related to adnexas (trichiasis, distichiasis, hordeolum, chalazion, epiblepharon, xanthelasma, ptosis, ectropion, entropion, benign and malignant tumors of the eyelids, proptosis, microphthalmos, anophthalmic eye socket, phthisis bulbi, disorders of lacrimal channels) and external eye (pterygium, pinguecula, symblepharon, benign and malignant conjunctival tumors) and traumas. Infections related to aesthetics as dermatochalasis and fatty pockets of the eyelids were excluded.

\section{RESULTS}

Among the 11000 individuals examined, 1581 diagnoses were made related to adnexas or external eye, with frequency of occurrence of $14.4 \%$ of involvement in the general population.

The most common disease was pterygium with 1035 cases detected (present in $9.41 \%$ of the population), 91 cases of hordeolum $(0.83 \%), 76$ cases of pinguecula $(0.69 \%) ; 74$ ectropium $(0.67 \%) ; 65$ traumas $(0.59 \%) ; 63$ ptosis $(0.57 \%) ; 52$ trichiasis $(0.5 \%), 33$ conjunctival nevi $(0.3 \%)$; 25 chalazion $(0.23 \%) ; 17$ xantelasmas $(0.15 \%), 12$ anophthalmic eye sockets $(0.11 \%), 9$ dacriostenosis $(0.08 \%), 7$ proptosis $(0.06 \%), 6$ basal cell carcinomas (BCC) $(0.05 \%), 5$ phthisis bulbi $(0.04 \%), 4$ squamous cell carcinomas (SCC) $(0.04 \%), 3$ epiblepharon $(0.04 \%), 2$ facial paralysis $(0.02 \%)$, one case of microphthalmos $(0.01 \%)$, and one case of symblepharon $(0.01 \%)$ (Graph 1$)$.

\section{Graph 1}

Frequency of diseases in the total population

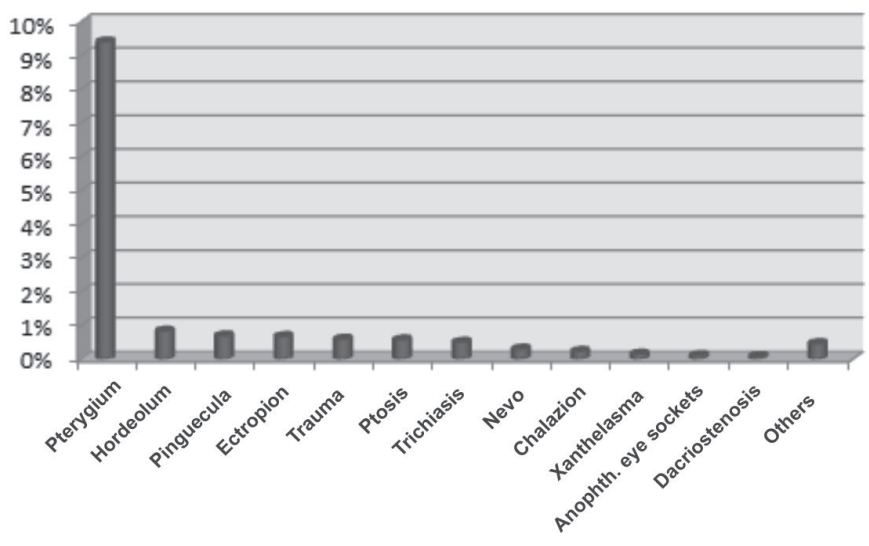

Considering the frequency of diseases with respect to gender, of the 1581 diagnoses, 730 were performed in men $(46.2 \%)$ and 851 in women $(53.8 \%)$. Taking into account the participation of the sexes in the population studied, $39.1 \%$ of participants were male, resulting in the estimated frequency of diagnoses of diseases in the adnexa or external eye for the male population of $17.0 \%$, and in the female population of $12.7 \%$ (Table 1 ).

Table 1

\section{Distribution of diseases in the adnexas and external eye according to the gender in the midwest region of the State of São Paulo, Brazil}

\begin{tabular}{llc}
\hline Disease & \multicolumn{1}{c}{ Males } & Females \\
\hline Pterygium & $475(11)[10.1 ; 12.0]$ & $560(8.4)[7.7 ; 9.0]$ \\
Hordeolum & $28(0.7)[0.4 ; 0.9]$ & $63(0.9)[0.7 ; 1.2]$ \\
Trauma & $45(1.0)[0.7 ; 1.3]$ & $20(0.3)[0.2 ; 0.4]$ \\
Pinguecula & $31(0.7)[0.5 ; 1.0]$ & $45(0.7)[0.5 ; 0.9]$ \\
Ptosis & $30(0.7)[0.4 ; 0.9]$ & $33(0.5)[0.3 ; 0.7]$ \\
Ectropion & $47(1.1)[0.8 ; 1.4]$ & $27(0.4)[0.3 ; 0.6]$ \\
Trichiasis & $30(0.7)[0.4 ; 0.9]$ & $22(0.3)[0.2 ; 0.5]$ \\
Conjunctival nerve $12(0.3)[0.1 ; 0.4]$ & $21(0.3)[0.2 ; 0.4]$ \\
Chalazion & $8(0.2)[0.1 ; 0.3]$ & $17(0.3)[0.1 ; 0.4]$ \\
Xanthelasma & $1(0.0)[0.0 ; 0.1]$ & $16(0.2)[0.1 ; 0.4]$ \\
Others & $23(0.5)[0.3 ; 0.7]$ & $27(0.4)[0.2 ; 0.6]$ \\
\hline
\end{tabular}

Total

$730(17.0 \%)[15.9 ; 18.1] \quad 851(13.4 \%)[11.9 ; 13.5]$

Values expressed in absolute number (percentage) [minimum percentage; maximum percentage] 
When the involvement of men and women is observed in accordance with each of the diseases, it is possible to observe important differences between genders. In the male population, pterygium, trauma and ectropion showed greater frequency than in the female population. The rest of the diseases showed frequency statistically similar between genders. Dacriostenosis, anophthalmic eye socket, phthisis bulbi, facial paralysis, symblepharon, microphthalmos, BCC, SCC, and proptosis had low expression in the population studied, being included in the table as others (Table 1).

Evaluation of the total diagnoses of interest made in the study population and its representation between them shows that pterygium accounted for $65.5 \%$ of the diagnoses related to adnexas or external eye. Other diagnoses and their percentages were: hordeolum $(5.8 \%)$, pinguecula $(4.8 \%)$, ectropion $(4.7 \%)$, trauma $(4.1 \%)$, ptosis $(4 \%)$, trichiasis $(3.3 \%)$, conjunctival nerve $(2.1 \%)$, chalazion $(1.6 \%)$ and other less frequent (4.2\%) (Graph 2).

\section{Graph 2}

\section{Distribution of diagnoses related to diseases of adnexas and external eye according to the percentage of frequency of occurrence among the diagnoses carried out}
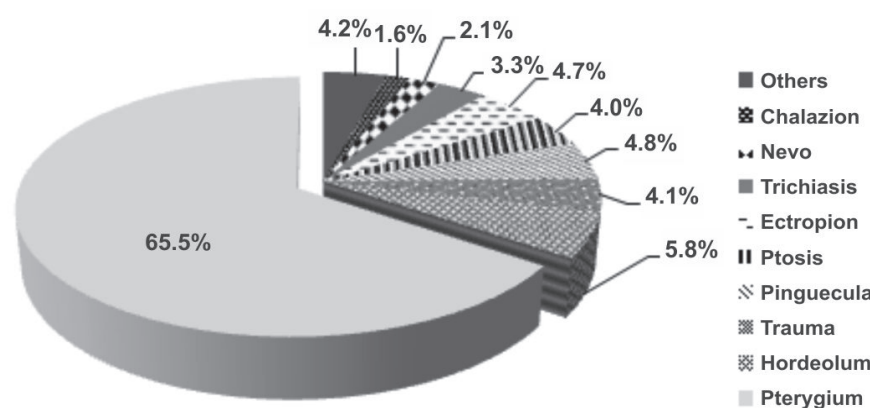

Is was necessary to continue the treatment for 405 individuals $(25.6 \%)$, who were referred to the reference service of the Single Health System in the region, generally for surgical treatment.

\section{Discussion}

The distribution of diseases in a random sample showed that approximately $14.4 \%$ of the diagnoses that can be found in the general population are related to adnexas or external eye. This information, as well as the frequency of occurrence of diseases in the population, are important because they can be used as parameter to establish priorities for the population care, as well as to guide training programs for undergraduates, residents of Ophthalmology or health officials.

The change mostly found in adnexas and in the ocular surface was pterygium, present in $9.4 \%$ of the total population and accounting for $65.5 \%$ among the diseases of interest located in adnexas or external eye, and affecting statistically more the male population (11\% B\& X 8.4\%@\&). Although pterygium still does not have a well-defined etiology, its relation to exposure to the Sun, wind, dust, heredity and dryness is indubitable. In the midwest region of São Paulo the predominance of farmworkers is notorious. In a Chinese study ${ }^{3}$, the prevalence of pterygium was $10.5 \%$ in a population also predominantly rural. It was noted that increasing age and exposure to the sun for more than 4 hours per day are associated to higher incidence of pterygium, whereas a higher educational level and the use of sunglasses were associated to a lower incidence of the disease. There was no statistically significant difference between men and women. A study in South Korea ${ }^{4}$, a country of predominantly industrial economy, showed that the prevalence of pterygium was $5.4 \%$, also affecting more men than women, similar to the present study.

This condition should be widely discussed in medical training, as well as in ophthalmologic residency, since currently there are several surgical techniques for excision and various discussions about their treatment with different outcomes ${ }^{5}$.

The tendency to have diseases with preference for males was also pointed out by others, especially when the subject is traumas $^{6}$ or changes related to sun exposure, such as ectropium occuring much more often in men ${ }^{7,8}$.

Hordeolum represented the second most frequent disease among diagnoses $(5.6 \%$ of the total), present in $0.8 \%$ of the general population, $0.6 \%$ of the male population and $1.2 \%$ of females. Often the origin is chronic inflammations of the eyelid margin such as blepharitis, and it may be related to the presence of refractive errors. It is a problem of easy treatment if properly conducted, preventing future chalazion formation, a disease that is also present in the study population in smaller percentages. Among the eyelid disorders treated in an emergency room, i.e., a study using a sample of convenience, the majority of cases $(90.9 \%)$ was of inflammatory or infectious origin, such as blepharitis, hordeolum and the chalazion ${ }^{9}$.

The diagnoses of diseases affecting the eyelid positioning (ectropion, ptosis, trichiasis) were present in $1.7 \%$ of the general population. Some important differences between these diseases can be noted, such as the ectropion detected in $0.7 \%$ of the population, but with no cases of entropion found. Another study ${ }^{10}$ showed that the frequency of entropion in another convenience sample is $2.1 \%$. In the Japanese population, entropion is much more common than ectropion $^{11}$.

The malposition of the eyelashes occurred in $0.5 \%$ of the study population, and it should be remembered that trichiasis may have chronic inflammation of palpebral margin as origin ${ }^{7}$, and trachoma is endemic in the region studied ${ }^{12}$.

Six cases of basal cell carcinoma $(0.05 \%)$ and four cases of squamous cell carcinoma $(0.04 \%)$ were diagnosed in the population and referred for surgical treatment. We emphasize that these individuals with malignant tumors were part of a random sample, and we may consider that the detection was made in a preventive exam. Despite the few cases of tumor detected, we call attention to the need for training in eyelid or external eye tumors, since the population may go to the general practitioner and ophthalmologist for other reasons besides the injury. The good clinical examination can provide good diagnostic accuracy, getting better according to the doctor's experience ${ }^{13}$ and assisting in early detection and conduct, which undoubtedly improves the prognosis.

Thus, our results point to the main complaints of adnexas and external eye, for which ophthalmologists should be prepared for diagnosis and treatment, with emphasis on pterygium, ectropion, ptosis and trichiasis. 


\section{Conclusion}

O pterígio foi a afecção do olho externo mais diagnosticada na população de estudo. Das afecções dos anexos, o hordéolo e as alterações do posicionamento palpebral foram as mais frequentes. Todas estas afecções são facilmente identificáveis, preveníveis ou tratáveis. A detecção, a abordagem e as formas de tratamento devem ser amplamente ensinadas desde a graduação até para o oftalmologista e para agentes de saúde, a fim de que complicações tardias e irreversíveis ao olho sejam evitadas.

\section{REFERENCES}

1. Cruz AA, Chaud F, Guimarães FC. Patologia dos anexos oculares. Medicina, Ribeirão Preto.1997;30(1): 36-51.

2. Schellini SA, Zimmermann GP, Hoyama E, Padovani CR, Padovani CR. Alterações da margem palpebral associadas ao ectrópio. Arq Bras Oftalmol. 2005;68(5):619-22.

3. Jiao W, Zhou C, Wang T, Yang T, Yang S, Bi H, et al. Prevalence and risk factors for pterygium in rural older adults in Shandong Province of China: a cross-sectional study. Biomed Res Int. 2014. Article ID 658648, Available from: http://dx.doi.org/10.1155/2014/ 658648

4. Yoon KC, Mun, GH, Kim, SD, Kim HD, Kim, CY, Park, KH et al. Prevalence of eye diseases in South Korea: data from the Korea National Health and Nutrition Examination Survey. Korean J Ophthalmol. 2011;25(6):421-33.

5. Torres-Gimeno A, Martínez-Costa L, Ayala G. Preoperative factors influencing success in pterygium surgery. BMC Ophthalmol. 2012;12:38. DOI: 10.1186/1471-2415-12-38

6. Cai M, Zhang J. Epidemiological characteristics of workrelated ocular trauma in southwest region of China. Int $\mathrm{J}$ Environ Res Public Health 2015;12(8):9864-75.
7. Veloso CE, Schellini SA, Padovani CR, Padovani CRP. Ectrópio palpebral: características e relação com alterações óculopalpebrais. Rev Bras Oftalmol. 2006;65(3):147-51.

8. Wanzeler ACV, Nascimento MF, Sousa RL, Padovani CR, Schellini SA. Alterações palpebrais: frequência de ocorrência e perfil dos portadores em amostra populacional brasileira. Rev Bras Oftalmol. 2015;74(4): 231-4

9. Netto AA, Rolim AP, Müller TP, Prevalência de doenças palpebrais no serviço emergencial de oftalmologia do Hospital Universitário da Universidade Federal de Santa Catarina. ACM Arq Catarin Med. 2006; 35(4):64-9.

10. Damasceno RW, Osaki MH, Dantas PE, Belfort Jr R. Involutional entropion and ectropion of the lower eyelid: prevalence and associated risk factors in the elderly population. Ophthal Plast Resconstr Surg 2011;27(5):317-20.

11. Carter SR, Chang J, Aquilar GL, Rathbun JE, Seiff SR. Involutional entropion and ectropion of the Asian lower eyelid. Ophthal Plast Reconstr Surg. 2000;16(1):45-9.

12. Schellini SA, Sousa RL. Tracoma: ainda uma importante causa de cegueira. Rev Bras Oftalmol. 2012; 71(3):199-204.

13. Rossato LA, Carneiro RC, Miyazaki A, Matayoshi S. Acurácia do exame clínico no diagnóstico de lesões palpebrais Rev Bras Oftalmol. 2014; 73(6):324-8.

\section{Corresponding author}

Maria Júlia de Barros Orsolini

Departamento de Oftalmologia, Otorrinolaringologia e

Cirurgia de Cabeça e Pescoço

Faculdade de Medicina de Botucatu - UNESP. Distrito de

Rubião Junior s/n CEP: 18618-000 Botucatu - SP-Brasil.

E-mail: majuorsolini@gmail.com 